\title{
Seasonal dynamics of Zooplankton functional groups in relation to environmental variables in Xiquanyan Reservoir, Northeast China
}

\author{
Patteson Chula Mwagona ${ }^{1}$, Ma Chengxue ${ }^{1,2, *}$ and Yu Hongxian ${ }^{1, *}$ \\ ${ }^{1}$ Department of Wetland, Wildlife Resource College, Northeast Forestry University, 26 Hexing Road, Xiangfang District, \\ Harbin 150040, PR China \\ ${ }^{2}$ Chinese Academy of Fishery Sciences, Heilongjiang River Fisheries Research Institute, Harbin, PR China
}

Received: 10 July 2018; Accepted: 18 September 2018

\begin{abstract}
In this study, the concept of functional feeding groups was used to classify and model the seasonal variation of zooplankton functional groups in relation to environmental variables. A total of 48 zooplankton species were observed in the reservoir and grouped into 8 functional groups. Both environmental variable and the biomass of zooplankton functional groups vary spatially and seasonally. Water temperature, water transparency, total nitrogen and nitrates were significantly higher in summer, while chlorophyll- $a$ and ammonium were higher in autumn and spring, respectively. Biomass of zooplankton was significantly higher in summer $(245.81 \mu \mathrm{g} / \mathrm{L})$, followed by autumn $(196.54 \mu \mathrm{g} / \mathrm{L})$ and spring $(54.25 \mu \mathrm{g} / \mathrm{L})$. Group RF (rotifer filter feeders) dominated in spring, accounting for $80 \%$ of the total biomass. In summer and autumn, group RC (rotifer carnivore) and SCF (small copepods and cladocerans filter feeders) were the dominant, respectively. Total nitrogen, total phosphorus, ammonium, chlorophyll- $a$ and water transparency were the major factor influencing zooplankton community. Group RF was positively influenced by ammonium and total phosphorus, while RC, SCF and MCF (middle copepods and cladocerans filter feeders) were positively correlated with chlorophyll- $a$. Top-down control of phytoplankton by groups $\mathrm{RC}, \mathrm{SCF}$ and MCF in Xiquanyan reservoir is not strong enough to produce negative effect. Increase in predator size biomass did not strengthen top-down control on prey. It is quite clear that the zooplankton function groups of Xiquanyan reservoir followed a predictable seasonal pattern. This therefore highlights the significance of environmental variables in structuring plankton composition in the reservoir.
\end{abstract}

Keywords: zooplankton / functional groups / biomass / seasonal / spatial / environmental variables

\section{Introduction}

Water is an important resource in any scene that involves life. As a result of socio-economic and population growth, the global water demand has been rising steadily and is projected to continue to increase in the near future. In order to meet the increasing demand of water, human beings have been intervening in the natural water cycles to make more water available. For instance, dams and reservoirs have been constructed to supply water for irrigation and other anthropogenic users. Construction of reservoirs along rivers for water supplies has altered the natural flow pattern, linkages with floodplain lead to the discontinuity of river physical structures which may cause the reduction of ecological

\footnotetext{
*Corresponding author: china.yhx@163.com/mch007@163.com
}

diversity of river communities such as zooplankton (Martinet et al., 2014; Shen et al., 2014).

Zooplanktons are among the top most important organisms in aquatic systems. They have been documented to actively transport particles to deeper part of aquatic systems through vertical migration (Jónasdóttir et al., 2015). By feeding on particle aggregates, zooplanktons play a major role in breaking down organic matter, and thus are involved in nutrients' cycling (Schneider-Olt and Adrian, 2001; Turner, 2015). Additionally, as grazers in reservoirs and lakes, zooplanktons may influence phytoplankton dynamics and hence the relationship between nutrients and chlorophyll (Tessier et al., 2001). Changes in zooplankton diversity and abundance have been used as indicator for human and climate variability effect on the functioning of the ecosystem (Auer et al., 2004; Benedetti et al., 2018). Recently, the use of functional traits to model variation in zooplankton biomass in aquatic systems has gained much attention (Araújo et al., 2006; Kishi et al., 2007; 
Benedetti et al., 2015). Functional traits are the behavioral, morphological or phonological characteristics of organisms that impact their ecological role and fitness in their niches (Araújo et al., 2006; Benedetti et al., 2015). Initially, the functional traits approach of classifying zooplankton relied on limited number of size classes only, which poorly captured the dynamics of zooplankton community (Quere et al., 2005; Litchman et al., 2013). Several trait-based approaches such as the use of morphological traits (body size/length) and lifehistory traits (mode of feeding) have been proposed and used to classify and asses zooplankton dynamics in marine, lakes and large river ecosystems (Araújo et al., 2006; Sun et al., 2010). However, the functional trait approach remains to be used in classifying and assessing the variations of zooplankton community in relation to environmental variables in reservoirs such as Xiquanyan.

Xiquanyan Reservoir was built in 1992 with the main objective of supplying drinking water to the millions of people living in Harbin city and Heilongjiang province. The main sources of water to the reservoir are Ashihe river, Huangni river and Erdao river. While assessing the phytoplankton community structure and trophic status of Xiquanyan reservoir, $\mathrm{Ma}$ and $\mathrm{Yu}$ (2013) revealed that the reservoir is mesotrophic and the phytoplankton community varies seasonally as a result of changes in environmental factors, mainly nutrients. This seems to be the only existing published study on Xiquanyan reservoir despite its importance. In this study, the concept of functional feeding groups was used to model the seasonal variation of zooplankton functional groups in relation to environmental variables in Xiquanyan reservoir. Understanding the variation of the biomass of zooplankton functional groups in relation to environmental variables is very important to (1) develop more realistic models and (2) better understand the environmental variables that significantly structure the zooplankton community in the reservoir. This will form an important source of information to be used in implementing correct management practices in order to maintain water quality of the reservoir in a perspective of multiple-use approach. This study aims (1) at identifying and classifying zooplankton species of Xiquanyan reservoir into functional group and (2) to determine the seasonal and spatial dynamics of the biomass of zooplankton functional groups and their relationship to environmental variables. We hypothesized that seasonal and spatial change in biomass of zooplankton functional groups will be strongly influenced by environmental variables.

\section{Methods}

\subsection{Study area}

Xiquanyan Reservoir $\left(127^{\circ} 16^{\prime}-127^{\circ} 22^{\prime}\right.$ E, $45^{\circ} 11^{\prime}-45^{\circ} 15^{\prime}$ $\mathrm{N})$ is situated at about $84 \mathrm{~km}$ southeast of Acheng District in Harbin of Heilongjiang province Northeastern China (Fig. 1). The region is under the influence of continental monsoon with a mean annual temperature and rainfall of about $3.9^{\circ} \mathrm{C}$ and $540 \mathrm{~mm}$, respectively. During winter season, the entire surface of the reservoir is covered by ice. The reservoir was constructed in 1992 and is used, among many other purposes, to supply water to the Harbin city, which has about 10 million inhabitants. Xiquanyan Reservoir has a surface area of
$40.86 \mathrm{~km}^{2}$, a capacity of $4.7 \times 10^{8} \mathrm{~m}^{3}$ and an average depth of $11.6 \mathrm{~m}$. The reservoir is classified as mesotrophic (Ma and $\mathrm{Yu}, 2013)$ and it receives water from Ashihe river, Huangni river and Erdao river with about $68 \%$ of the flow occurring from June to September.

\subsection{Field sampling and analysis}

\subsubsection{Sample collection}

Based on the shape of the reservoir, sampling sites were selected taking into consideration the maximum representation of the reservoir. Samples were collected $(0.5 \mathrm{~m}$ from the surface water) on monthly basis (April, May, July, August, September and October) from 9 georeferenced sites (S1-S9) inside the Xiquanyan Reservoir (Fig. 1). April and May were clustered for spring, July and August for summer and September and October for autumn. Sites S1-S4 were located near the discharge point of the rivers into the reservoir (upstream of the reservoir), sites S5- S8 were located at the middle of the reservoir and site $\mathrm{S} 9$ was located near the outflow of the reservoir (downstream of the reservoir). At every sampling site, water temperature, $\mathrm{pH}$, conductivity and dissolved oxygen was measured in the field using a portable multiprobe (YSI 6600, YSI Inc., USA). Water transparency and turbidity were measured using Secchi disk and turbidimeter, respectively.

Triplicates unfiltered water samples for measurements of nutrients, chlorophyll- $a$ and zooplankton were collected at $0.5 \mathrm{~m}$ from the surface using a calibrated van Dorn sampler. Water samples for nutrients analysis were put on acid-washed plastic bottles, placed in ice box and transported to laboratory for analysis. The nutrients analysis (total nitrogen, ammonium, nitrate, and total phosphorus and chemical oxygen demand) was done according to the environmental quality standards for surface water of China (MEP, Ministry of Environmental Protection, 2002). Biomass of phytoplankton in terms of chlorophyll- $a$ concentration was determined according to the protocols for standard observation and measurement in aquatic ecosystems by filtering $100 \mathrm{~mL}$ of water through a GF/C whatman filter and the filters were put in a dark cooler and placed in ice box until analysis (Cai et al., 2007; Shen et al., 2014). Pigments extraction was done in $90 \%$ aqueous solution of acetone, and chlorophyll- $a$ concentrations were measured spectrometrically.

Zooplankton samples $(10 \mathrm{~L}$ of water filtered through $64 \mathrm{~mm}$ mesh size) were fixed using formaldehyde solution (4\% final concentration). The concentrated samples were allowed to sediment in a $1-\mathrm{L}$ jar for at least $24 \mathrm{~h}$. Supernatant water was carefully decanted and the residual collected and made to a known volume $50 \mathrm{~mL}$ as described in literature (Huang, 1981; Thompson et al., 2013). Triplicates subsamples of $10 \mathrm{~mL}$ aliquot of the condensed sample were counted when zooplankton abundance was very high; otherwise, the whole condensed sample was analyzed. Identification of the zooplankton species was done using an inverted microscope at $400 \times$ magnification following the species keys (Chen, 1974; Haney et al., 2013; Kotov et al., 2013). The biomass of the zooplankton functional groups was computed by dividing dry weight $(\mathrm{mg})$ obtained from length-weight relation of the species to the volume of water (L) filtered (McCauley, 1984; Sun et al., 2010). 


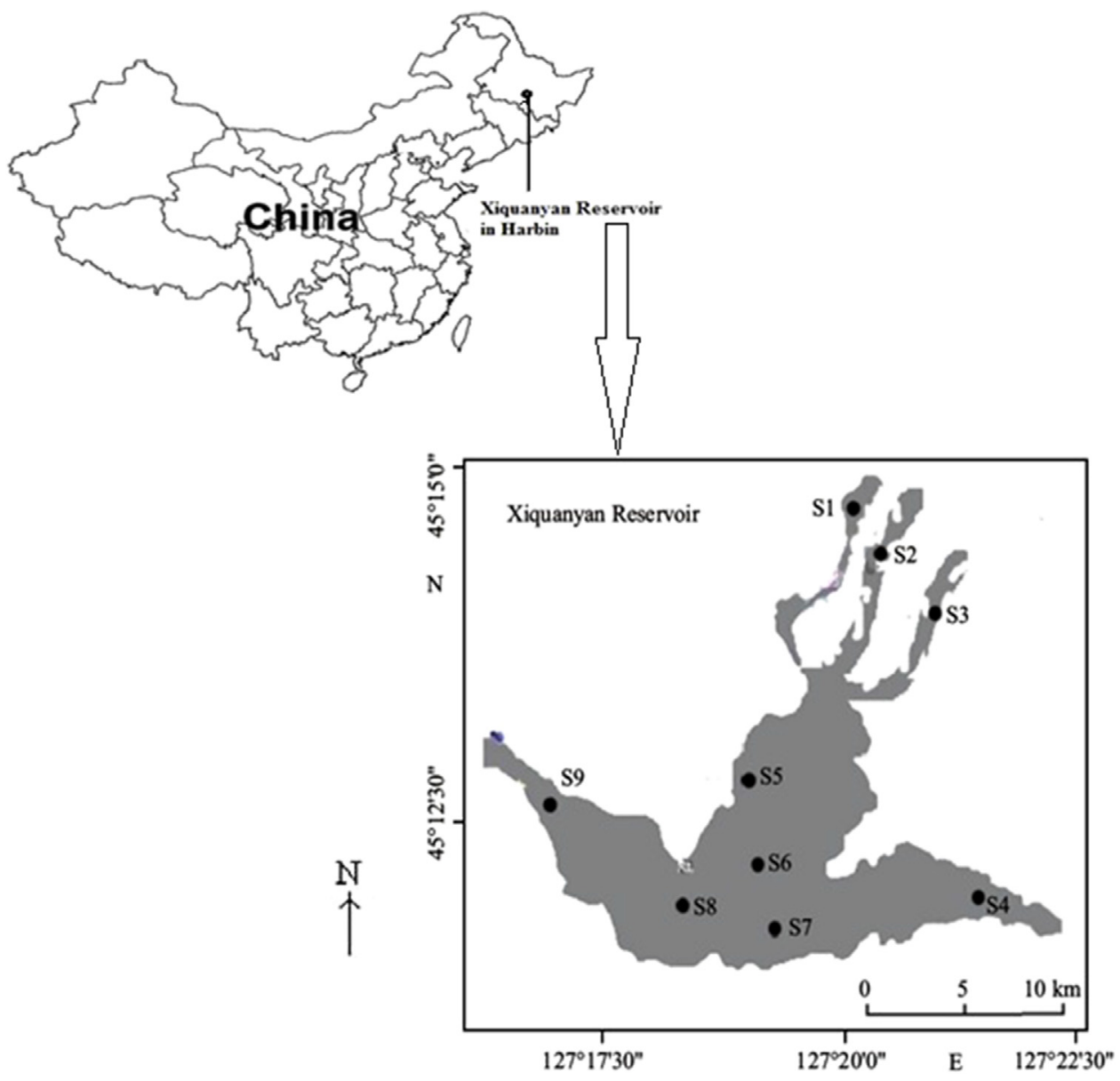

Fig. 1. Map of China with insert of Xiquanyan Reservoir in the Northeast China showing the distribution of sampling sites (S1-S9).

\subsubsection{Classification of zooplankton functional group}

The sampled zooplankton species in Xiquanyan Reservoir were classified into eight functional groups based on their body size/length and mode of feeding (Benedetti et al., 2018; Ma et al., accepted for publication). The eight functional groups are protozoa filter feeders (PF), protozoa carnivore (PC), rotifer filter feeders (RF), rotifer carnivore (RC), small copepods and cladocerans filter feeders (SCF), middle copepods and cladocerans filter feeders (MCF), middle copepods and cladocerans carnivore (MCC) and large copepods and cladocerans carnivore (LCC). PF and RF are passive filter feeders feeding on organic detritus, bacteria and algae. $\mathrm{RC}$ and $\mathrm{PC}$ are ambush feeders that target small motile prey (other zooplanktons). RC group was mainly dominated by Asplanchna priodonta and Asplanchna girodi (Tab. 2). Functional group SCF included those species with body size $<0.7 \mathrm{~mm}$ that mostly feed through filter-feeding on bacteria, algae, organic detritus and protozoa. This group was mainly represented by Bosmina coregoni and Microcyclops javanus. Group MCF included those zooplankton individuals with body length in the range of $0.7-1.5 \mathrm{~mm}$. Just like SCF, MCF is a filter-feeder feeding on bacteria, algae, organic detritus and protozoa. Ecologically, MCF plays a major role as a food source for fish and also can control algal blooms. Species in
MCF group included Microcyclops inchoatus, Paracyclops affims, Paracyclops fimbrtatus, Diaphanosoma leuchtenbergianum and Alona Baird sp. MCC consists of middle copepods and cladocerans of body size in the range of $0.7-1.5 \mathrm{~mm}$ that mainly feed through ambush tactics. This group mainly feeds on rotifer, oligochaeta, chironomidae larvae and other cladoceran, thereby competing with fish for food resources in the aquatic systems. Group MCC was represented by only four species: Macrocyclops albidus, Thermocyclops dybowskii, Thermocyclops vermifer and Acanthocyclops vernalis. Functional group LCC constitutes carnivore copepods and cladocerans of body length greater than $1.5 \mathrm{~mm}$ and was composed by Leptodora kindti and Cyclops furcifer. LCC group feeds on other zooplankton and it forms an important food source for fish (Meerhoff et al., 2007).

\subsection{Data analysis}

Before analysis, all the environmental variables and biomass of zooplankton functional groups were tested for normality using Kolmogorov-Smirnov test and homogeneity of the data was tested using Bartlett test. Environmental variables and biomass of zooplankton functional groups which were found to be skewed were $\log (x+1)$ transformed to satisfy 
Table 1. Means values \pm standard error $(n=43)$ of environmental variables of the Xiquanyan reservoir. Differences between the seasons were tested by Tukey HSD ANOVA. Values with same superscripts in each column are not significantly different.

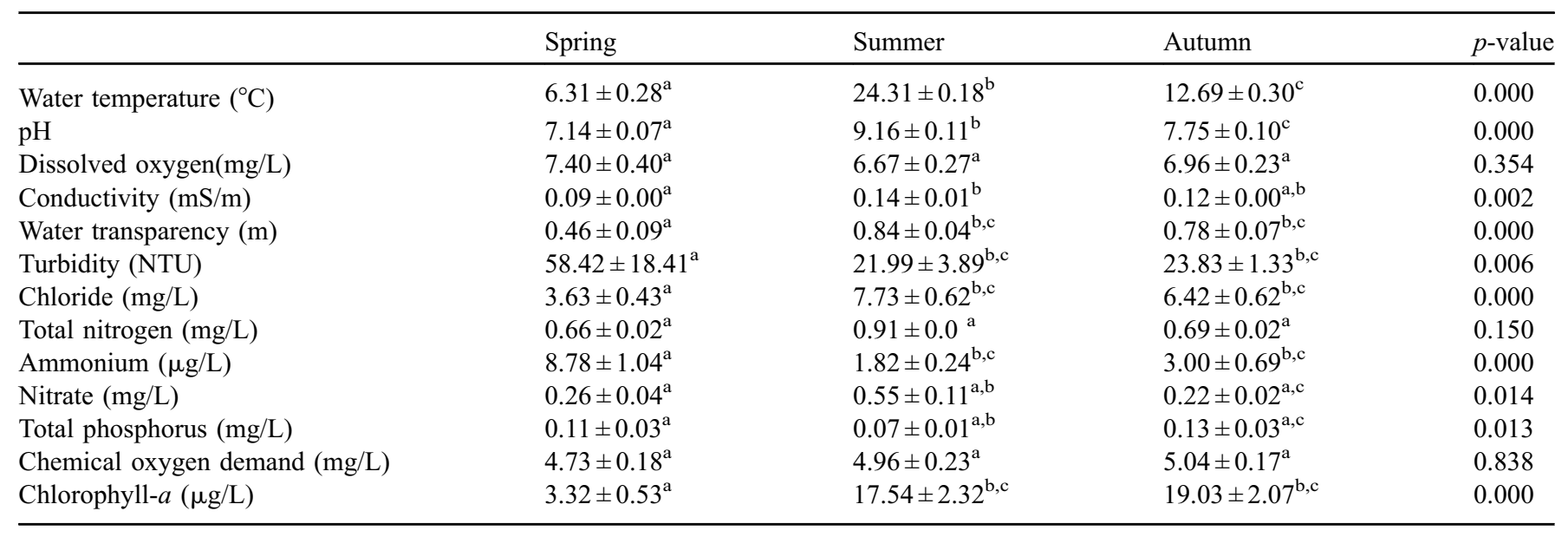

the normality and variance assumption before conducting analysis. Principal component analysis (PCA) was used to assess the possible relations between environmental variables. PCA is an ordination method used to reduce the dimensionality of multivariate data sets and enable graphical representation of relationship between variables (Sharma et al., 2017). Variance analysis (two-way ANOVA) with sites and seasons as main factors was used to determine the seasonal and spatial variations of environmental variables and the biomass of zooplankton functional groups. A Post Hock Tukey HSD test was applied to identify sources of variation if there were statistically significant difference detected among seasons or sites using ANOVA. A detrended corresponding analysis of the eight zooplankton functional groups indicated that the gradient length of the four axes was 2.17. Therefore, linear ordination method of the redundancy analysis (RDA) was used to test the relationship between environmental variables and the biomass of zooplankton functional groups (Shen et al., 2014; Šmilauer and Lepš, 2014). This was done through a stepwise forward selection procedure based on $p$ values from 999 Monte Carlo permutation test. Pearson correlation analysis was done to confirm the significant relationships between environmental variables and the biomass of zooplankton functional groups. Figures were drawn using Microsoft Excel and R software (version 3.4.1) (Team, 2014). Unless otherwise indicated, the results are reported as mean value \pm standard error (SE).

\section{Results}

\subsection{Environmental variables}

The average seasonal values of environmental variables recorded among the sampling sites within the Xiquanyan reservoir are shown in Table 1. Most of the variables revealed statistically significant variations with respect to seasons (twoway ANOVA and Tukey HSD test); $p<0.05$. However, dissolved oxygen, total nitrogen and chemical oxygen demand were not statistically significant difference among the seasons.
According to Badsi et al. (2010), water temperature is one of the essential factors that regulate the growth of zooplankton in aquatic systems. From our results, water temperature depicted a significant seasonal variation $\left(F_{(2,34)}=1276.24, p<0.001\right)$ with higher significant mean value recorded in summer $\left(24.31^{\circ} \mathrm{C}\right)$ than in autumn $\left(12.69^{\circ} \mathrm{C}\right)$ and spring $\left(6.31^{\circ} \mathrm{C}\right)$. Spatially, no significant difference was observed for water temperature among the sites. Statistically significant differences among seasons were observed for $\mathrm{pH}(p=0.000)$, with the highest value occurring in summer (9.16) and lowest in spring (7.14). Just like $\mathrm{pH}$, the highest values of conductivity and chloride were observed in summer of $0.14 \mathrm{~ms} / \mathrm{m}$ and $7.73 \mathrm{mg} / \mathrm{L}$, respectively (Tab. 1). Although relatively higher mean dissolved oxygen was recorded in spring, no statistically significant variations were observed among the seasons $\left(F_{(2,34)}=1.072 p=0.354\right)$. Significant differences among seasons and sites were observed for both water transparency and turbidity (Tab. 1; Figs. 2b and 2c). Higher water transparency was observed in summer when turbidity was low. Spatially, sites located upstream of the reservoir recorded higher turbidity and low water transparency than those located middle and downstream of the reservoir. In relation to nutrients, the mean total nitrogen measured in summer was higher than for the other seasons; however, no distinct seasonal variations pattern in total nitrogen was observed. Tukey HSD test indicated that ammonium determined in spring, nitrate in summer and total phosphorus in autumn season were significantly higher than in the other seasons. Total phosphorus did not show any significant differences spatial. However, ANOVA revealed a significant difference in total phosphorus among the seasons. Tukey HSD Post hoc test indicated that the mean total phosphorus determined in summer was significantly lower that than in autumn. The overall mean biomass of phytoplankton in terms of chlorophyll- $a$ was $15.00 \mu \mathrm{g} / \mathrm{L}$ (Tab. 1), with the highest value $(19.03 \mu \mathrm{g} / \mathrm{L})$ observed during autumn. Tukey HSD test revealed that the mean chlorophyll- $a$ in spring was statistically significantly lower $(3.32 \mu \mathrm{g} / \mathrm{L})$ compared to that of autumn $(19.03 \mu \mathrm{g} / \mathrm{L})$ and summer $(17.54 \mu \mathrm{g} / \mathrm{L})$. Based on the chlorophyll- $a$ concentrations values, Xiquanyan reservoir 
P.C. Mwagona et al.: Ann. Limnol. - Int. J. Lim. 2018, 54, 33
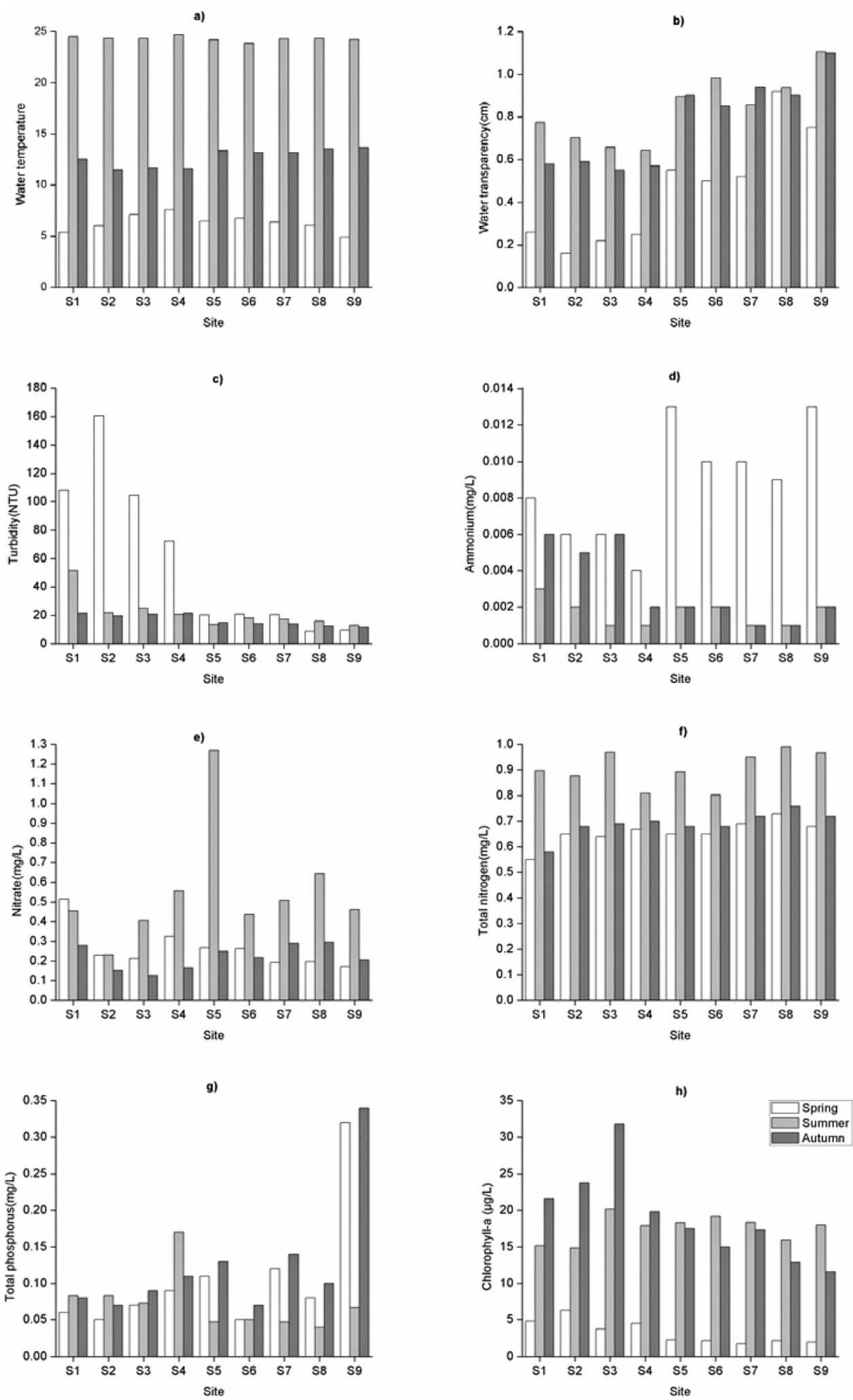

Fig. 2. Spatial variations of selected environmental variables of the Xiquanyan reservoir in different seasons. 


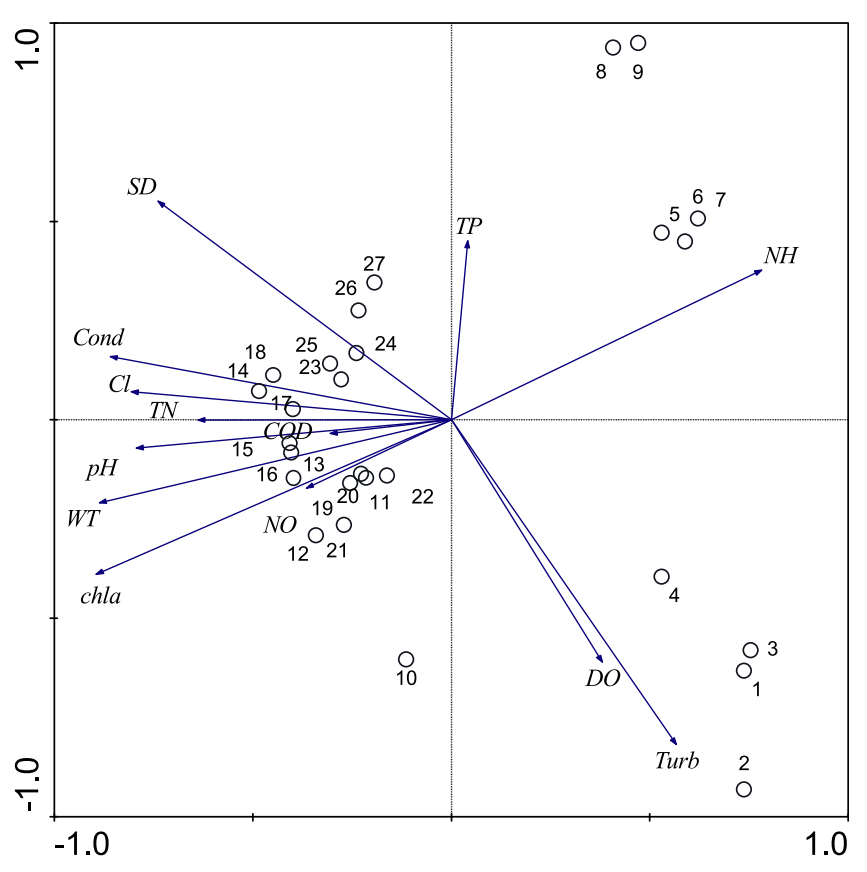

Fig. 3. Principal component analysis (PCA) for the environmental variables of the Xiquanyan reservoir. Circle numbers 1-9, 10-18 and 19-27 indicate sampling in spring, summer and autumn, respectively. Environmental variables: $\mathrm{DO}=$ dissolved oxygen; Cond = conductivity; $\mathrm{SD}=$ water transparency; Turb=turbidity; $\mathrm{Cl}=$ chloride; $\mathrm{TN}=$ total nitrogen; $\mathrm{NH}=$ ammonium; $\mathrm{NO}=$ nitrate; $\mathrm{TP}=$ total phosphorus; $\mathrm{COD}=$ chemical oxygen demand; Chla $=$ chlorophyll $-a$.

can be categorized as of mesotrophic system during spring season and slightly eutrophic system in summer and autumn seasons (Klapper, 1991). Spatially, sites located upstream of the reservoir had a relative high mean value for chlorophyll- $a$ (Fig. 2h).

The principal components analysis (PCA) using 13 environmental variables explained $71.22 \%$ of data variability in the first two components (component $1=52.41 \%$; component $2=18.81 \%$ ) (Fig. 3). In component 1 , the most important environmental variables were water temperature (0.926), conductivity (0.924), $\mathrm{pH}(0.922)$, chloride (0.877), ammonium $(-0.843)$, total nitrogen $(0.830)$, water transparency $(0.785)$, chlorophyll- $a(0.704)$, nitrate $(0.567)$, turbidity $(-0.564)$ and dissolved oxygen $(-0.513)$. With respect to component 2 , the most important environmental variable for its ordination were total phosphorus $(-0.812)$, turbidity (0.681) and dissolved oxygen (0.678). The PCA results revealed that component 1 reflected higher warming gradient, redox potential gradient, increased trophic status and water clarity in the seasons of summer and autumn. Positively, component 1 (sampling units of summer and autumn seasons) was correlated with water temperature, conductivity, $\mathrm{pH}$, chloride, total nitrogen, water transparency, chlorophyll-a and nitrates and negatively correlated with ammonium, turbidity and dissolved oxygen. On its positive side, the sampling units in spring were correlated with turbidity and dissolved oxygen and negatively correlated with total phosphorus.

\subsection{Zooplankton community in Xiquanyan reservoir}

During the study period, 48 zooplankton species belonging to four taxonomic categories: protozoans, rotifers, copepods and cladocerans were observed in the Xiquanyan reservoir (Tab. 2). Rotifers were composed of 19 species equivalent to $39.58 \%$, followed by protozoans with $14(29.17 \%)$, copepods 8 $(16.67 \%)$ and cladocerans $4(8.33 \%)$. The highest number of species collected was in summer (41 species) followed by autumn (28 species) and spring ( 7 species). In summer, group $\mathrm{RC}$ was mainly represented by $A$. priodonta and $A$. girodi, while functional group MCC was represented by $M$. albidus, T. dybowskii, T. vermifer and A. vernalis. Small copepods and cladocerans filter feeders (SCF) were represented by $B$. coregoni and $M$. javanus. In autumn, group RC was mainly dominated by $A$. priodonta, while group MCC was represented by $T$. dybowskii, M. albidus and A. vernalis. Group LCC was represented only by $L$. kindti.

\subsection{Seasonal and spatial variation of zooplankton functional groups}

The mean biomass of all zooplankton functional group differed significantly among the seasons as determined by two-way ANOVA $\left(F_{(2,43)}=3.654 p=0.041\right)$. A Tukey HSD test showed that the total mean biomass was statistically significantly lower in spring $(54.25 \pm 40.22 \mu \mathrm{g} / \mathrm{L})$ compared to that in autumn $(196.54 \pm 53.56 \mu \mathrm{g} / \mathrm{L})$ and summer $(245.81 \pm 58.02 \mu \mathrm{g} / \mathrm{L})$. In spring, functional group $\mathrm{RF}$, dominated mainly by Gastropus stylifer, was dominant with a mean biomass of $43.42 \pm 37.88 \mu \mathrm{g} / \mathrm{L}$, which corresponded to about $80 \%$ of the total biomass (Fig. 4). Functional group MCC also accounted for about $8.36 \%$ (mean biomass $4.54 \pm 1.75 \mu \mathrm{g} / \mathrm{L}$ ) of the total biomass in spring. With exception of site S2, all the sites were dominated by group RF (Fig. 5a). In summer, functional group RC accounted the highest mean biomass of $91.25 \mu \mathrm{g} / \mathrm{L}$ (35.81\%) followed by MCC $36.27 \mu \mathrm{g} / \mathrm{L}(14.75 \%)$, SCF $34.66 \mu \mathrm{g} / \mathrm{L}(14.10 \%)$, LCC $27.22 \mu \mathrm{g} / \mathrm{L}(11.07 \%)$ and $\mathrm{PF} 23.56 \pm 11.92 \mu \mathrm{g} / \mathrm{L}(9.58 \%)$ (Fig. 4). The mean biomass contribution by groups RF and PC in summer was less than $10 \mu \mathrm{g} / \mathrm{L}$. Spatially, groups RC, SCF, MCC and MCF were present in almost all sites in summer. However, functional group LCC contributed large percentage of biomass in sites located middle and downstream of the reservoir (Fig. 5b). In autumn, the relative biomass contribution by groups SCF, RC, MCC and LCC were almost similar (Fig. 4). Group SCF, mainly represented by B. coregoni, accounted for about $52.68 \pm 27.40 \mu \mathrm{g} / \mathrm{L}(26.80 \%)$ of the total biomass. Groups RC, MCC and LCC accounted for $48.41 \pm 38.03 \mu \mathrm{g} / \mathrm{L} \quad(24.63 \%), 47.44 \pm 21.10 \mu \mathrm{g} / \mathrm{L} \quad(24.18 \%)$ and $38.88 \pm 15.91 \mu \mathrm{g} / \mathrm{L}(19.78 \%)$ of the total biomass in autumn, respectively. Spatially, sites located upstream (S1-S4) were dominated by group RC, while groups SCF, MCC and LCC co-dominated in sites located middle and downstream of the reservoir (Fig. 5c).

\subsection{Environmental variables related to the biomass of zooplankton functional groups}

The RDA ordination of the biomass of zooplankton functional groups with respect to environmental variables are 
P.C. Mwagona et al.: Ann. Limnol. - Int. J. Lim. 2018, 54, 33

Table 2. Zooplankton species composition observed in Xiquanyan reservoir listed according to their functional groups and their percentage contribution to their total biomass $(*)=$ present.

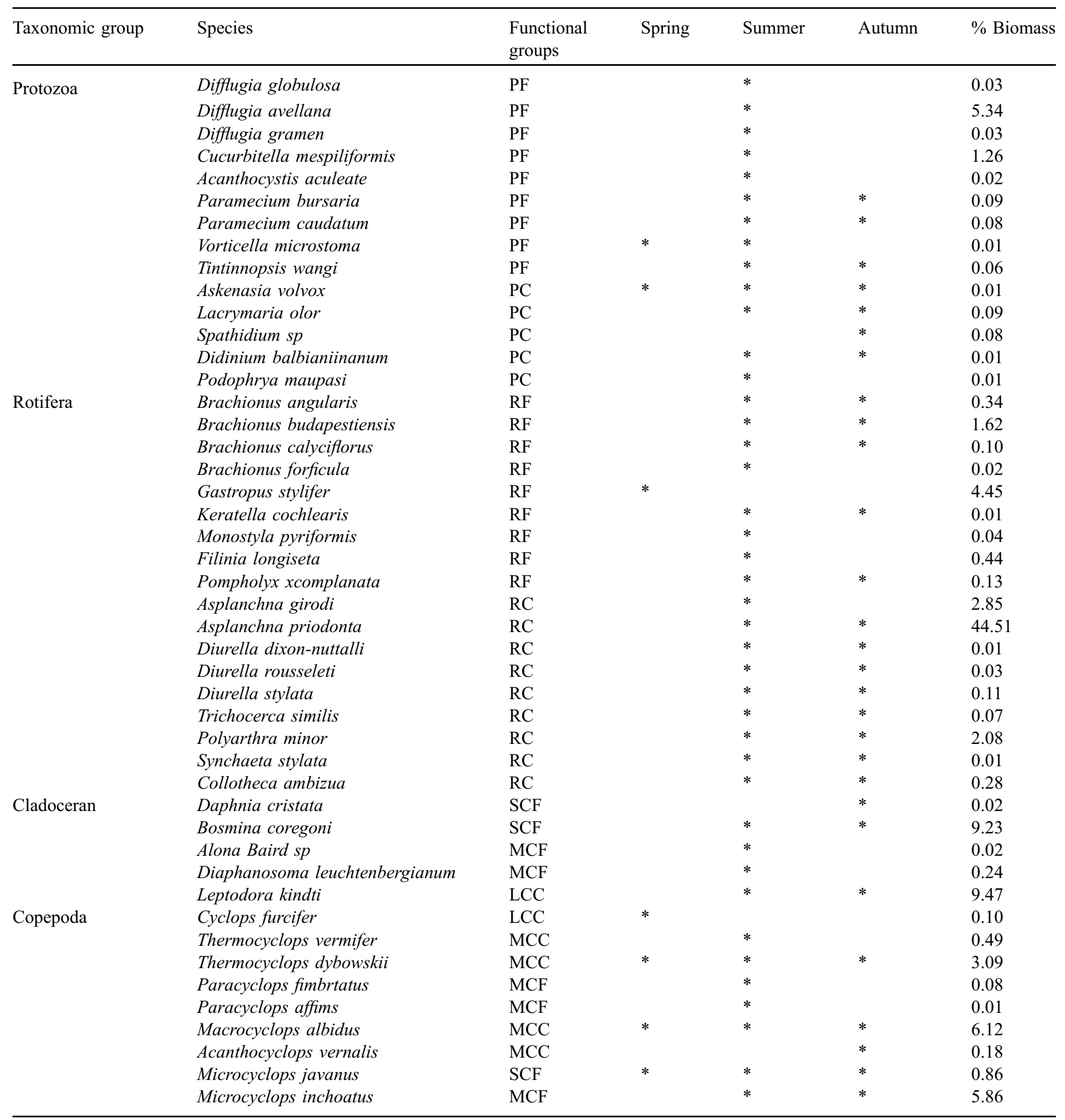

presented in Figure 6. The first two RDA axes explained $61.7 \%$ (axis 1: $47.2 \%$; axis $2: 14.5 \%$ ) of the variation in the biomass of zooplankton functional groups data and $76.3 \%$ (axis $1: 58.4 \%$; axis $2: 17.9 \%$ ) of the functional groups-environment variables relationship. Using the function ordistep from the vegan package to conduct forward selection and screening of the environmental variables yielded five variables that were significant to the model. These five variables are total nitrogen $(F=5.299, P=0.010)$, total phosphorus $(F=4.37, P=0.031)$, ammonium $(F=6.635, P=0.010)$, chlorophyll- $a(F=5.567$, $P=0.005)$ and water transparency $(F=9.582, P=0.005)$. These five variables accounted for $66.7 \%$ of the total variance 


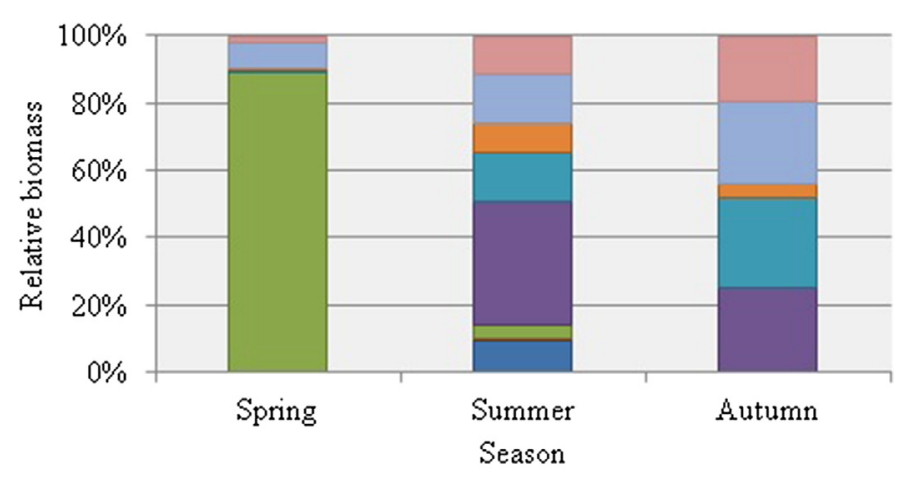

$\square \mathrm{PF} \square \mathrm{PC} \square \mathrm{RF} \square \mathrm{RC} \square \mathrm{SCF} \square \mathrm{MCF} \square \mathrm{MCC} \square \mathrm{LCC}$

Fig. 4. Seasonal variation in the relative biomass of zooplankton functional groups in Xiquanyan reservoir. Protozoa filter feeders (PF), protozoa carnivore (PC), rotifer filter feeders (RF), rotifer carnivore (RC), small copepods and cladocerans filter feeders (SCF), middle copepods and cladocerans filter feeders (MCF), middle copepods and cladocerans carnivore (MCC) and large copepods and cladocerans carnivore (LCC).

in the biomass of zooplankton functional groups. The first RDA axis was positively correlated to conductivity $(0.866)$, chloride (0.866), water temperature $(0.855), \mathrm{pH}(0.810)$, water transparency (0.755), total nitrogen (0.728), and chlorophyll- $a$ $(0.714)$ and negatively to ammonium $(-0.924)$, and turbidity $(-0.535)$. Axis 2 was negatively correlated with chlorophyll- $a$ $(-0.672)$.

The biomass of functional group PF was positively correlated with water temperature, $\mathrm{pH}$, conductivity, total nitrogen, chloride and nitrate (as indicated by the similar directions of their arrows in Fig. 6). A multiple forward stepwise regression indicated that total nitrogen was the most important variable related to the biomass of group PF (Biomass of $\mathrm{PF}=1.060+2.482$ total nitrogen, $F_{(2,43)}=27.37, p=0.000$, $\left.R^{2}=0.523\right)$. Group RF, which accounted for about $80 \%$ of the total biomass in spring, was positively associated with ammonium and total phosphorus the gradient of trophic status and negatively related by water temperature, chlorophyll- $a$ and $\mathrm{pH}$ (as indicated by the directions of the arrows). Group RC had a positive relationship with chlorophyll- $a$, water temperature, $\mathrm{pH}$, total nitrogen and conductivity with about $76.9 \%$ of its biomass variation explained by chlorophyll- $a$ and total nitrogen $(\mathrm{RC}=-0.026+0.657$ chlorophyll- $a+1.625$ total nitrogen $\left.F_{(2,43)}=39.88, p=0.010, R^{2}=0.769\right)$. Groups SCF, MCC, MCF and LCC were positively related to water transparency, water temperature, $\mathrm{pH}$, conductivity, chloride and total nitrogen and negatively to turbidity, dissolved oxygen and ammonium. Forward stepwise regression selection with the biomass of SCF as response variable revealed ammonium and total phosphorus as important variables with a significant $F$-value that significantly increase the regression sum of squares $(\mathrm{SCF}=-2.584-0.766$ ammonium +0.415 total phosphorus, $\left.F_{(2,43)}=34.163, p=0.010, R^{2}=0.74\right)$. Approximately $76.1 \%$ of the variation in the biomass of MCC could be explained by ammonium, turbidity and chlorophyll- $a$ according to the model ( $\mathrm{MCC}=-1.69-0.755$ ammonium, -0.276 turbidity, -0.319 chlorophyll- $a, F_{(2,43)}=24.364, p=0.000$,
$\left.R^{2}=0.761\right)$. On the other hand, the biomass of LCC group was significantly influenced by water transparency $(\mathrm{LCC}=1.068+$ 0.997 water transparency, $\left.F_{(2,43)}=13.63, p=0.001, R^{2}=0.353\right)$. From the Pearson correlation analysis (Tab. 3), group RF was negatively correlated with chlorophyll- $a$, while groups PC, RC and SCF were positively correlated. Functional group PF was strongly positively correlated with groups PC and RC, and weakly but positively correlated with MCF and MCC. Groups SCF, MCf, MCC and LCC were positively correlated.

\section{Discussion}

\subsection{Zooplankton functional group}

According to Benedetti et al. (2015), Violle et al. (2007) and Reynolds et al. (2002), functional traits are the behavioral, morphological or phonological characteristics of organisms that impact their ecological role and fitness in their niches. In plankton communities, for instance, these traits include body size, shape, motility, tolerance and sensitivity to environmental conditions among many others (Reynolds et al., 2002; Litchman et al., 2013; Benedetti et al., 2018). For sometimes now, classification of aquatic organisms into functional groups has been proposed to be the best way of understanding their ecological interaction (Hébert et al., 2016). Sun et al. (2010) classified zooplankton species of the continental shelf of yellow sea into six functional groups based on size spectrum and food preference. While modeling food web interaction in Western English channel ecosystem, Araújo et al. (2006) came up with three functional groups of macrozooplankton, mesozooplankton and microzooplankton. Recently, the functional traits including feeding mode, maximum body length, trophic group and spawning strategy have been used to classify plankton copepods (Benedetti et al., 2018). This approach has proved it worth when it comes to addressing the question at hand. Based on body size/length and mode of feeding, zooplankton species observed in the Xiquanyan reservoir were classified into eight functional groups PF, PC, RF, RC, SCF, MCF, MCC and LCC. Body size and mode of feeding are regarded as "master traits" that not only scale with different traits related to ecosystem processes such as secondary production and nutrients and carbon cycling but also describe the main food source of an organism, hence its role in aquatic food-web dynamics (Pomerleau et al., 2015; Hébert et al., 2016).

\subsection{Variation in zooplankton functional groups}

According to Shi et al. (2015), biomass is one of the most important variable when modeling temporal and spatial variation of zooplankton functional groups in aquatic systems. However, it has been applied sparingly for modeling zooplankton community structure in oligo-mesotrophic reservoir (Beaver et al., 2013; Sellami et al., 2016) such as Xiquanyan. In this study, the biomass of zooplankton functional groups varied significantly among seasons and sites. The average biomass recorded in spring $(54.25 \mu \mathrm{g} / \mathrm{L})$, summer $(245.81 \mu \mathrm{g} / \mathrm{L})$ and autumn $(196.54 \mu \mathrm{g} / \mathrm{L})$ was much lower compared to those reported by $\mathrm{Ma}$ et al.(accepted for 


\section{a) Spring}

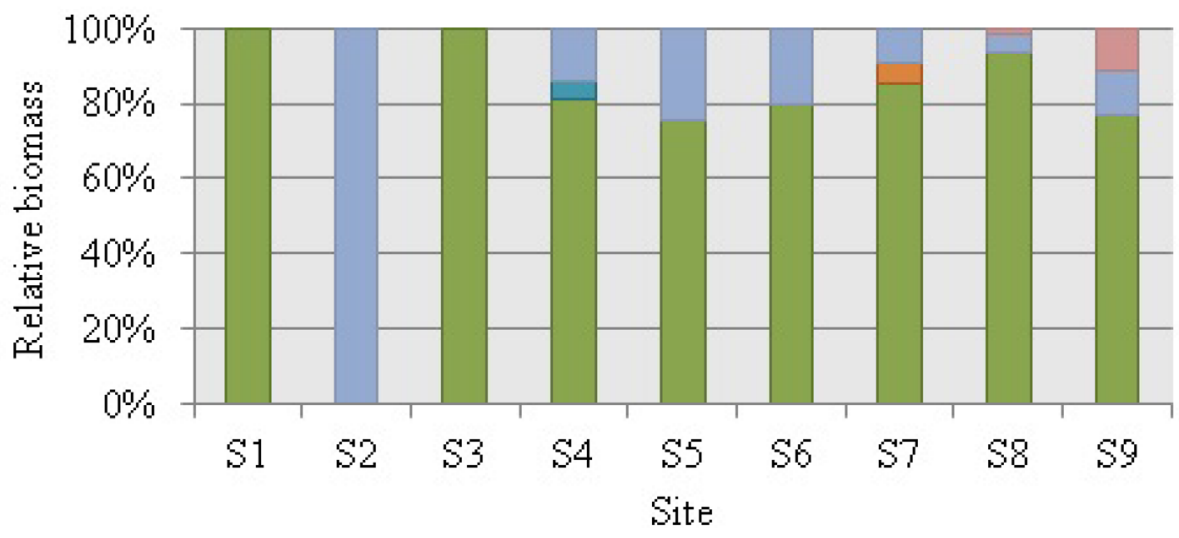

$\square \mathrm{FF} \square \mathrm{FC} \quad \square \mathrm{RF} \quad \square \mathrm{RC} \quad \square \mathrm{SCF} \square \mathrm{MCF} \square \mathrm{MCC} \square \mathrm{LCC}$

\section{b) Summer}

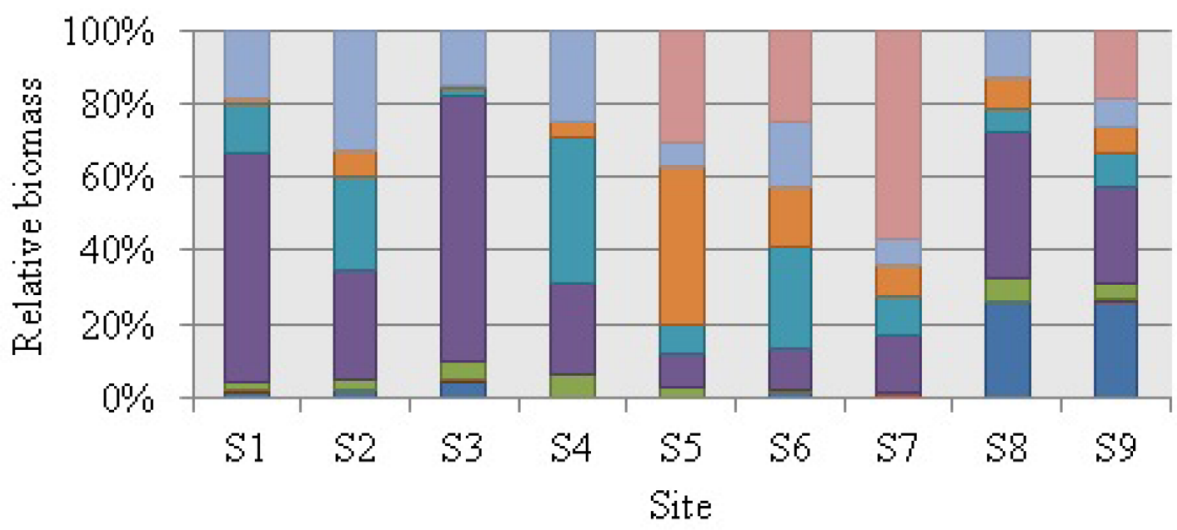

$\square \mathrm{PF} \square \mathrm{PC} \square \mathrm{RF} \quad \mathrm{RC} \quad \square \mathrm{SCF} \square \mathrm{MCF} \square \mathrm{MCC} \square \mathrm{LCC}$

c) Autumn

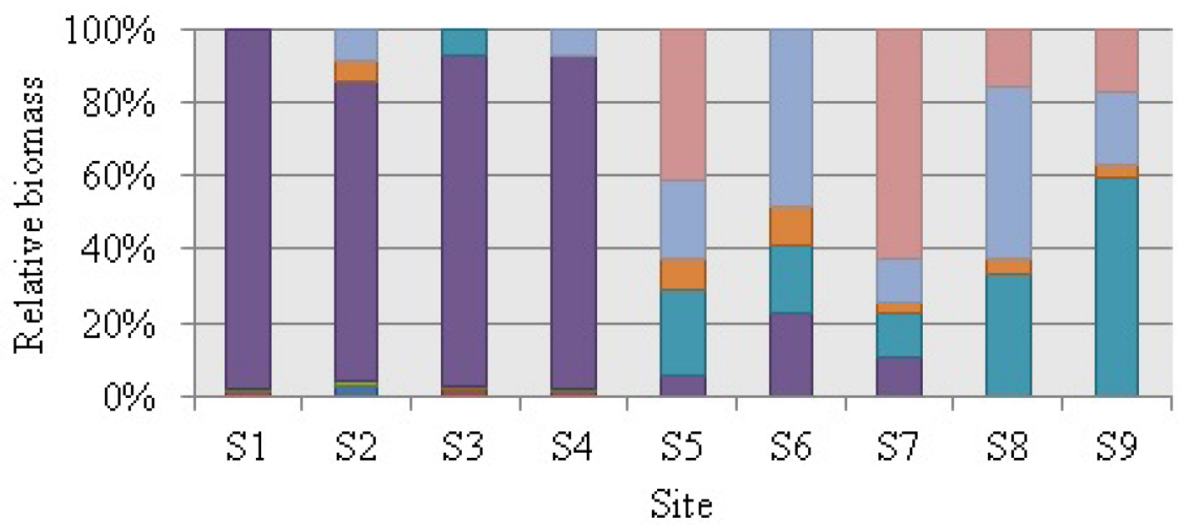

$\square \mathrm{PF} \square \mathrm{PC} \square \mathrm{RF} \square \mathrm{RC} \quad \mathrm{SCF} \square \mathrm{MCF} \square \mathrm{MCC} \square \mathrm{LCC}$

Fig. 5. Spatial variations biomass of zooplankton functional groups in Xiquanyan reservoir: (a) spring, (b) summer, (c) autumn. 
publication) for Small Xingkai Wetland Lake of autumn $(0.72 \mathrm{mg} / \mathrm{L})$, summer $(5.11 \mathrm{mg} / \mathrm{L})$ and spring $(0.28 \mathrm{mg} / \mathrm{L})$. During spring season, zooplankton biomass was dominated by RF mainly composed of $G$. stylifer accounting for about $80 \%$ of the total biomass. Spatially, this group was found in all sites except site $\mathrm{S} 2$. Higher biomass of RF group in spring coincided with higher ammonium and total phosphorus and very low temperature (mean value $6.31^{\circ} \mathrm{C}$ ) and chlorophyll- $a$ $(<4 \mu \mathrm{g} / \mathrm{L})$. Such observations are not strange, because RF species are filter-feeders feeding on bacteria-detritus suspension which could have been favored by the occurrence of higher concentrations of total phosphorus and total nitrogen (Duggan et al., 2001; Špoljar et al., 2005). While assessing spatial-temporal dynamics of planktonic rotifers in the Elbe Estuary, Germany, Holst et al. (1998) established that rotifers

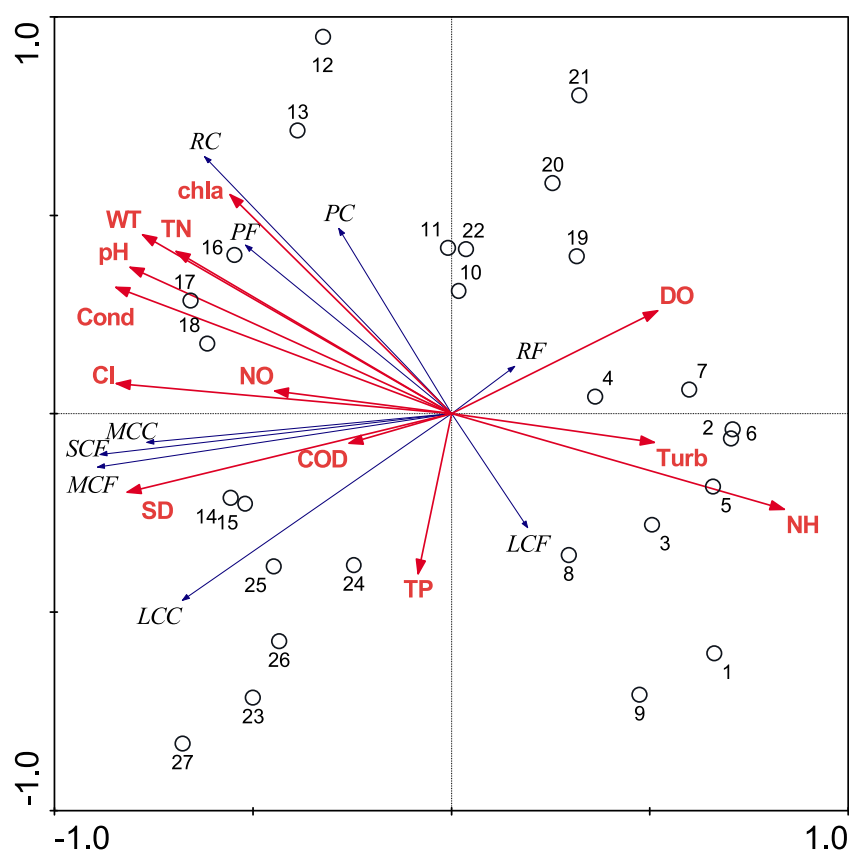

Fig. 6. Redundancy analysis (RDA) ordination diagram of zooplankton functional groups (blue lines with black letters) and environmental variables (red lines with red letters) in Xiquanyan reservoir. grazed predominantly on heterotrophic components of the microbial food-web, such as bacteria, detritus and heterotrophic flagellates in spring. Apart from food, water temperature is an important environmental variable that affects rotifer population abundance and seasonal succession (Dumont, 1983; Berzinš and Pejler, 1989; Yin et al., 2017). Several studies have found strong positive relationship between rotifers biomass and temperature (Galkovskaja, 1987). However, our results revealed that the biomass of RF was high in spring despite the fact that temperature was very low. This observation could be explained by (i) low temperature created hostile and unpredicted environment which allows rotifers an opportunistic and r-strategist organisms to flourish by eliminating other resource species competitor, (ii) high temperature has been reported to have negative effect on some species of rotifers. For example, Persaud and Williamson (2005) observed that exposure to ultraviolet light and high temperature had a remarkable effect on the reproduction and abundance of four rotifer species: G. stylifer, Kellicottia bostonensis, Kellicottia longispina, Keratella spp. Therefore, the dominance of G. stylifer, the only representative of RF group in spring, could be attributed by the favorable low temperatures. In fact G. stylifer was not found in summer or autumn when the temperature was relatively higher. Note, however, that, in their study, Pinese et al. (2015) and Yin et al. (2017) cautions that the concept of rotifer seasonal occurrence should be separated from the great dependence of changes in temperature since these processes among the zooplankton species are difficult to systematize due to the variety of interactions involved. Therefore, it is possible that other factors such as lack of exploitive competition from other filter feeders such as SCF and MCF and predation from MCC and LCC lead to the general high biomass of RF in spring (Fussmann, 1996; Brandl, 2005; Gilbert, 2014).

Rotifer carnivore ( $\mathrm{RC})$ an ambush feeder group that targets small motile 536 prey dominated zooplankton biomass during summer (35.81\%) followed by MCC (14.75\%), SCF (14.10\%) and LCC (11.07\%). Group RC was mainly represented by genus $A$. priodonta, a common rotifer distributed from tropical to temperate waters (Fernando et al., 1990). According to Chang et al. (2010), A. priodonta is an omnivore rotifer that feeds on phytoplankton dominated by dinoflagellates and protozoa prey such as Codonella spp. and Difflugia spp. It is

Table 3. Pearson correlation coefficients between zooplankton functional groups and with the biomass of phytoplankton in terms of chlorophyll- $a$; ${ }^{*} p<0.05 ;{ }^{*} p<0.01$.

\begin{tabular}{|c|c|c|c|c|c|c|c|c|}
\hline & $\mathrm{PF}$ & $\mathrm{PC}$ & $\mathrm{RF}$ & $\mathrm{RC}$ & SCF & $\mathrm{MCF}$ & $\mathrm{MCC}$ & $\mathrm{LCC}$ \\
\hline $\mathrm{PF}$ & 1 & $0.672 * *$ & 0.307 & $0.668^{* *}$ & 0.321 & $0.446^{*}$ & $0.395^{*}$ & 0.056 \\
\hline $\mathrm{RF}$ & & & 1 & -0.123 & -0.195 & -0.110 & 0.126 & -0.281 \\
\hline $\mathrm{RC}$ & & & & 1 & $0.407^{*}$ & $0.415^{*}$ & $0.429 *$ & -0.039 \\
\hline $\mathrm{SCF}$ & & & & & 1 & $0.836^{* *}$ & $0.798 * *$ & $0.609^{* *}$ \\
\hline $\mathrm{LCC}$ & & & & & & & & 1 \\
\hline
\end{tabular}


documented that the abundance and biomass of $A$. priodonta in a habitat is often influenced primarily by food source rather than predation pressure (Fernando et al., 1990; Yoshida et al., 2003). This agrees with our study since $A$. priodonta was found to be positively correlated with phytoplankton biomass in terms of chlorophyll- $a$. Spatially, group RC accounted for more than $50 \%$ of the total biomass in sites located upstream of the reservoir where chlorophyll- $a$ was very high. Group SCF mainly composed by $B$. coregoni depicted almost similar distribution pattern to that of RC (A. priodonta) with relative high biomass values observed in sites located upstream of the reservoir coinciding with higher chlorophyll- $a$ values. This observation is not surprising since other studies have shown $B$. coregoni to be efficient filter feeder of phytoplankton biomass (Guo et al., 2009). On the other hand, the low biomass contribution by RC in sites located middle and downstream of the reservoir can be probably explained by predation from MCC and LCC.

Almost similar biomass contribution pattern by the zooplankton functional group to that of summer were observed in autumn. However, unlike in summer, the biomass contribution by the SCF, RC, MCC and LCC were almost similar in autumn which led to the question: Is there any competitive interaction between those functional groups in this reservoir during autumn? Since these functional groups have different ecological requirement and resource utilization, we may think that competitive interaction was probably avoided. Furthermore, coexistence of the groups does not ensure competition because, in general, species explore different ecological niches and resources are not always limiting. In fact, our results revealed that group RC preferred sites located upstream of the reservoir where water transparency was very low and there were no SCF, MCC or LCC groups. Probably group RC was avoiding competition interaction especially from SCF group or predation from MCC and LCC groups. The evidence that rotifers (such as RC group species) could be preyed by copepods and cladocerans carnivore is pointed out by Brandl (2005). In the site located middle and downstream of the reservoir, the biomass contribution by SCF, MCC and LCC was almost similar probably because of their different morphological mechanisms for food resource exploitation. Protozoa, which are the main contributors to PF and PR functional groups in the reservoir investigated, exhibited no obvious seasonal and spatial variation and their contribution to the total biomass was very minimal. This could have been attributed by depressed exploitative competition for food resources from other functional groups such as MCF, RF and SCF as well as predation.

\subsection{Zooplankton functional groups driving factors in Xiquanyan reservoir}

Different studies have established that water temperature, food resources, predation, water transparency, nutrients and hydrology are important drivers that influence structuring of zooplankton community (Sommer et al., 1986, 2012; Shi et al., 2015; Sharma et al., 2017). Similarly, this current study has revealed that the zooplankton functional groups are influence by environmental variables that vary with season in Xiquanyan reservoir. From the RDA results, group RF was positively influenced by ammonium and total phosphorus. This relation may be the indirect result of food availability in the form of bacteria-detritus suspension, which have been documented to be strongly influenced by higher concentration of nutrients (Špoljar et al., 2005). The biomass of RF group was negatively correlated with chlorophyll- $a$. This may be explained in different ways: (i) strong top-down control on phytoplankton by RF group, which is contrary to what is documented in other studies that zooplankton are ineffective in controlling phytoplankton in reservoir (von Rückert and Giani, 2008; Okuku et al., 2016), (ii) high chlorophyll- $a$ concentration could be attributed to blue-green algae and green algae that contain some toxic extracellular substance which can cause decline in number and reproduction rate of rotifers (Arnold, 1971; Ger et al., 2014), and (iii) some studies have shown that rotifers (macrofilter-feeders species) abundance were negatively correlated with algal bloom in Oligo-mesotrophic Nabhana Reservoir because algal bloom eliminated the fine micro-algae which serve as food of micro-filter feeders (Sellami et al., 2016).

The fact that the biomass of groups RC, SCF and MCF were positively correlated with chlorophyll- $a$ could mean that the top-down control was not strong enough to produce negative effect on phytoplankton production. This also suggests that phytoplankton have an important role in energy transfer along the Xiquanyan reservoir food web, and phytoplankton particles are probably edible to the zooplankton functional groups. Similar observations were reported by Ismail and Adnan (2016) in two small man-made lakes in Malaysia. This observation has implications for the quantification of phytoplankton biomass in terms of chlorophyll- $a$ within Xiquanyan reservoir, as it appears that groups RC, SCF and MCF may be equally as significant in utilizing chlorophyll- $a$ directly. Moreover, groups RC and MCF were positively correlated with groups $\mathrm{PF}$ and $\mathrm{PC}$, which could imply that these protozoans served as important additional food for these functional groups probably at a time with limited supply of edible algae. In fact, Adamczuk et al. (2015) and Marzolf (1990) noted that phytoplankton alone does not satisfy all of the nutritional requirements of zooplankton. Top-down control of SCF, MCF and MCC by LCC seems to be not as important as indicated by their positive correlation. This could mean that increasing predator size biomass in reservoir does not strengthen top-down control on prey.

\section{Conclusion}

In this current study, a total of 48 zooplankton species belonging to four taxonomic categories (protozoans, rotifers, copepods and cladocerans) were identified and grouped into eight functional groups PF, PC, RF, RC, SCF, MCF, MCC and LCC. Both environmental variable and the biomass of zooplankton functional groups in Xiquanyan reservoir vary spatially and seasonally. Water temperature, water transparency, total nitrogen and nitrates were significantly higher in summer, while chlorophyll- $a$ and ammonium were higher in autumn and spring, respectively. The biomass of zooplankton functional groups was significantly higher in summer $(245.81 \mu \mathrm{g} / \mathrm{L})$, autumn $(196.54 \mu \mathrm{g} / \mathrm{L})$ and spring $(54.25 \mu \mathrm{g} / \mathrm{L})$. In spring group, RF was the dominant functional group accounting for about $80 \%$ of the total biomass. In summer 
and autumn, group RC and SCF were the dominant, respectively. Nutrients, mainly total nitrogen, total phosphorus and ammonium, chlorophyll- $a$ and water transparency were identified as the major factors influencing zooplankton functional groups in Xiquanyan reservoir. Group RF was positively influenced by ammonium and total phosphorus, while RC, SCF and MCF were positively correlated with chlorophyll- $a$. This clearly shows that the top-down control of phytoplankton by groups RC, SCF and MCF in Xiquanyan reservoir is not strong enough to produce negative effect. Moreover, increase in predator size biomass (e.g. LCC) does not strengthen top-down control on prey. Even though our study may not be conclusive as such, it is quite clear that the zooplankton functional groups of Xiquanyan reservoir followed a predictable seasonal pattern. This, therefore, highlights the significance of environmental variables in structuring plankton composition in the reservoir.

Acknowledgements. This study was supported by the Fundamental Research Funds for the Central Universities (2572018BE03) and Central-level Non-profit Scientific Research Institute Special Funds under grant (HSY 201511).

\section{References}

Adamczuk M, Mieczan T, Nawrot D, Rechulicz J. 2015. Indirect effect of environmental factors on interactions between microbial and classical food webs in freshwater ecosystems. Ann Limnol - Int J Lim: 49-58.

Araújo JN, Mackinson S, Stanford RJ, Sims DW, Southward AJ, Hawkins SJ, Ellis JR, Hart PJ. 2006. Modelling food web interactions, variation in plankton production, and fisheries in the western english channel ecosystem. Mar Ecol Prog Ser 309: 175-187.

Arnold, DE. 1971. Ingestion, assimilation, survival, and reproduction by Daphnia pulex fed seven species of blue-green algae. Limnol Oceanogr 16: 906-920.

Auer B, Elzer U, Arndt H. 2004. Comparison of pelagic food webs in lakes along a trophic gradient and with seasonal aspects: influence of resource and predation. J Plankton Res 26: 697-709.

Badsi H, Ali HO, Loudiki M, El Hafa M, Chakli R, Aamiri A. 2010. Ecological factors affecting the distribution of zooplankton community in the Massa Lagoon (Southern Morocco). Afr $J$ Environ Sci Tech 4: 751-762.

Beaver JR, Jensen DE, Casamatta DA, Tausz CE, Scotese KC, Buccier KM, Teacher CE, Rosati TC, Minerovic AD, Renicker TR. 2013. Response of phytoplankton and zooplankton communities in six reservoirs of the middle Missouri river (USA) to drought conditions and a major flood event. Hydrobiologia 705: 173-189.

Benedetti F, Gasparini S, Ayata SD. 2015. Identifying copepod functional groups from species functional traits. J Plankton Res 38 : 159-166.

Benedetti F, Vogt M, Righetti D, Guilhaumon F, Ayata SD. 2018. Do functional groups of planktonic copepods differ in their ecological niches? J Biogeogr 45: 604-616.

Berzinš B, Pejler B. 1989. Rotifer occurrence in relation to temperature. Hydrobiologia 175: 223-231.

Brandl, Z. 2005. Freshwater copepods and rotifers: predators and their prey. Hydrobiologia 546: 475-489.

Cai Q, Cao M, Huang X. 2007. Protocols for Standard Observation and Measurement in Aquatic Ecosystems. Beijing: Chinese Environmental Science Press (in Chinese).
Chang K-H., Hideyuki D, Nishibe Y, Nakano S-I. 2010. Feeding habits of omnivorous Asplanchna: comparison of diet composition among Asplanchna herricki, A. Priodonta and A. girodi in pond ecosystems. J Limnol 69: 209-216.

Chen Q-C. 1974. On planktonic copepods of the yellow sea and the East China Sea, II. Cyclopoida and Harpacticoida. Studia Marina Sinica 9: 1-24.

Duggan I, Green J, Shiel R. 2001. Distribution of rotifers in North Island, New Zealand, and their potential use as bioindicators of lake trophic state. Hydrobiologia 446: 155-164.

Dumont HJ. 1983. Biogeography of rotifers. Biology of Rotifers, Berlin: Springer, pp. 19-30.

Fernando C, Tudorancea C, Mengestou S. 1990. Invertebrate zooplankton predator composition and diversity in tropical lentic waters. In: Dumont HJ, Tundisi JG, Roche K., eds. Intrazooplankton Predation. Berlin: Springer, pp. 13-31.

Fussmann G. 1996. The importance of crustacean zooplankton in structuring rotifer and phytoplankton communities: an enclosure study. J Plankton Res 18: 1897-1915.

Galkovskaja G. 1987. Planktonic rotifers and temperature. Hydrobiologia 147: 307-317.

Ger KA, Hansson LA, Lürling M. 2014. Understanding cyanobacteria-zooplankton interactions in a more eutrophic world. Freshw Biol 59: 1783-1798.

Gilbert JJ. 2014. Morphological and behavioral responses of a rotifer to the predator Asplanchna. J Plankton Res 36: 1576-1584.

Guo N, Zhang M, Yu Y, Qian S, Li D, Kong F. 2009. Crustacean zooplankton communities in 13 lakes of Yunnan-Guizhou plateau: relationship between crustacean zooplankton biomass or size structure and trophic indicators after invasion by exotic fish. Ann Limnol - Int J Lim 45: 279-288.

Haney J, Aliberti M, Allan E, Allard S, Bauer D, Beagen W, Bradt S, Carlson B, Carlson S, Doan U. 2013. An image-based key to the zooplankton of North America, University of New Hampshire Center for Freshwater Biology.

Hébert M-P, Beisner BE, Maranger R. 2016. Linking zooplankton communities to ecosystem functioning: toward an effect-trait framework. J Plankton Res 39: 3-12.

Hébert MP, Beisner BE, Maranger R. 2016. A meta-analysis of zooplankton functional traits influencing ecosystem function. Ecology 97: 1069-1080.

Holst H, Zimmermann H, Kausch H, Koste W. 1998. Temporal and spatial dynamics of planktonic rotifers in the Elbe estuary during spring. Estuar Coast Shelf Sci 47: 261-273.

Huang X. 1981. Application of the simplified method of weight determination to various species of planktonic rotifers in lake Donghu, Wuhan. Acta Hydrobiol Sin 7: 409-416.

Ismail AH, Adnan AAM. 2016. Zooplankton composition and abundance as indicators of eutrophication in two small man-made lakes. Trop Life Sci Res 27: 31.

Jónasdóttir SH, Visser AW, Richardson K, Heath MR. 2015. Seasonal copepod lipid pump promotes carbon sequestration in the deep North Atlantic. Proc Natl Acad Sci USA 112: 1212212126.

Kishi MJ, Kashiwai M, Ware DM, Megrey BA, Eslinger DL, Werner FE, Noguchi-Aita M, Azumaya T, Fujii M, Hashimoto S. 2007. Nemuro: a lower trophic level model for the North Pacific marine ecosystem. Ecol Modell 202: 12-25.

Klapper H. 1991. Control of eutrophication in Inland Waters. Hertfordshire, UK: Ellis Horwood Ltd.

Kotov A, Forró L, Korovchinsky N, Petrusek A. 2013. World checklist of freshwater Cladocera species. World Wide Web electronic publication, 38 . 
Litchman E, Ohman MD, Kiørboe T. 2013. Trait-based approaches to zooplankton communities. J Plankton Res 35: 473-484.

Ma C, Yu H. 2013. Phytoplankton community structure in reservoirs of different trophic status, northeast China. Chin J Oceanol Limnol 31: 471-481.

Ma C, Mwagona PC, Yu H, Sun X, Liang L, Mahboob S. 2018. Seasonal dynamics of zooplankton functional group and its relationship with physicochemical variables in high turbid nutrientrich Small Xingkai Wetland Lake, Northeast China. J Freshw Ecol. DOI:10.1080/02705060.2018.1443847.

Martinet J, Descloux S, Guédant P, Rimet F. 2014. Phytoplankton functional groups for ecological assessment in young sub-tropical reservoirs: case study of the Nam-Theun 2 Reservoir, Laos, SouthEast Asia. J Limnol 73. DOI: https://doi.org/10.4081/jlim nol.2014.958

Marzolf G. 1990. Reservoirs as environments for zooplankton. Reservoir Limnology: Ecological Perspectives. New York: John Wiley \& Sons, Inc., pp. 195-208.

McCauley E. 1984. The estimation of the abundance and biomass of zooplankton in samples. In: Downing JA, Rigler F, eds. A Manual on Methods for the Assessment of Secondary Productivity in Fresh Waters. London: Blackwell Science Publishers, pp. 228-265.

Meerhoff M, Iglesias C, De Mello FT, Clemente JM, Jensen E, Lauridsen TL, Jeppesen E. 2007. Effects of habitat complexity on community structure and predator avoidance behaviour of littoral zooplankton in temperate versus subtropical shallow lakes. Freshw Biol 52: 1009-1021.

MEP (Ministry of Environmental Protection). 2002. China's National Standard: Gb3838-2002: Environmental Quality Standards for Surface Water.

Okuku EO, Tole M, Kiteresi LI, Bouillon S. 2016. The response of phytoplankton and zooplankton to river damming in three cascading reservoirs of the Tana river, Kenya. Lakes Reserv: Res Manag 21: 114-132.

Persaud AD, Williamson CE. 2005. Ultraviolet and temperature effects on planktonic rotifers and crustaceans in northern temperate lakes. Freshw Biol 50: 467-476.

Pinese OP, Pinese JF, Del Claro K. 2015. Structure and biodiversity of zooplankton communities in freshwater habitats of a vereda wetland region, Minas Gerais, Brazil. Acta Limnol Bras 27: 275-288.

Pomerleau C, Sastri AR, Beisner BE. 2015. Evaluation of functional trait diversity for marine zooplankton communities in the northeast subarctic pacific ocean. J Plankton Res 37: 712-726.

Quere CL, Harrison SP, Colin Prentice I, Buitenhuis ET, Aumont O, Bopp L, Claustre H, Cotrim Da Cunha L, Geider R, Giraud X. 2005. Ecosystem dynamics based on plankton functional types for global ocean biogeochemistry models. Glob Chang Biol 11: 2016-2040.

Reynolds CS, Huszar V, Kruk C, Naselli-Flores L, Melo S. 2002. Towards a functional classification of the freshwater phytoplankton. J Plankton Res 24: 417-428.

Schneider-Olt B, Adrian R. 2001. Trophic interactions between crustacean and protozoan plankton. Int Vereinigung Theor Angew Limnol: Verhandlungen 27: 3705-3707.

Sellami I, Hamza A, El Bour M, Mhamdi MA, Pinelalloul B, Ayadi H. 2016. Succession of phytoplankton and zooplankton communities coupled to environmental factors in the oligo-mesotrophic Nabhana reservoir (semi arid mediterranean area, central Tunisia). Zool Stud 55. DOI: 10.6620/ZS.2016.55-30

Sharma AS, Gupta S, Singh NR. 2017. Zooplankton community of Keibul Lamjao National Park (KLNP) Manipur, India in relation to the physico-chemical variables of the water. Chin J Oceanol Limnol 35: 469-480.

Shen H, Li B, Cai Q, Han Q, Gu Y, Qu Y. 2014. Phytoplankton functional groups in a high spatial heterogeneity subtropical reservoir in China. J Great Lakes Res 40: 859-869.

Shi Y-Q, Sun S, Zhang G-T, Wang S-W, Li C-L. 2015. Distribution pattern of zooplankton functional groups in the yellow sea in June: a possible cause for geo graphical separation of giant jellyfish species. Hydrobiologia 754: 43-58.

Šmilauer P, Lepš J. 2014. Multivariate Analysis of Ecological Data Using Canoco 5. Cambridge, UK: Cambridge University Press.

Sommer U, Adrian R, De Senerpont Domis L, Elser JJ, Gaedke U, Ibelings B, Jeppesen E, Lürling M, Molinero JC, Mooij WM. 2012. Beyond the plankton ecology group (PEG) model: mechanisms driving plankton succession. Annu Rev Ecol Evol Syst 43: 429-448.

Sommer U, Gliwicz ZM, Lampert W, Duncan A. 1986. The PEGmodel of seasonal succession of planktonic events in fresh waters. Arch Hydrobiol 106: 433-471.

Špoljar M, Habdija I, Primc-Habdija B, Sipos L. 2005. Impact of environmental variables and food availability on rotifer assemblage in the Karstic Barrage Lake Visovac (Krka River, Croatia). Int Rev Hydrobiol 90: 555-579.

Sun S, Huo Y, Yang B. 2010. Zooplankton functional groups on the continental shelf of the yellow sea. Deep Sea Res Part 2 Top Stud Oceanogr 57: 1006-1016.

Team RC. 2014. R: a language and environment for statistical computing. R Foundation for Statistical Computing, Vienna, Austria. ISBN 3-900051-07-0.

Tessier AJ, Bizina EV, Geedey KC. 2001. Grazer: resource interactions in the plankton: are all daphniids alike. Limnol Oceanogr 46: 1585-1595.

Thompson GA, Dinofrio EO, Alder VA. 2013. Structure, abundance and biomass size spectra of copepods and other zooplankton communities in upper waters of the southwestern Atlantic Ocean during summer. J Plankton Res 35: 610-629.

Turner JT. 2015. Zooplankton fecal pellets, marine snow, phytodetritus and the ocean's biological pump. Prog Oceanogr 130: 205-248.

Violle C, Navas ML, Vile D, Kazakou E, Fortunel C, Hummel I, Garnier E. 2007. Let the concept of trait be functional! Oikos 116: 882-892.

von Rückert G, Giani A. 2008. Biological interactions in the plankton community of a tropical eutrophic reservoir: is the phytoplankton controlled by zooplankton? J Plankton Res 30: 1157-1168.

Yin L, Ji Y, Zhang Y, Chong L, Chen L. 2017. Rotifer community structure and its response to environmental factors in the Backshore Wetland of Expo Garden, Shanghai. Aquac Fish 3: 90-97.

Yoshida T, Urabe J, Elser JJ. 2003. Assessment of 'top-down'and 'bottom-up' forces as determinants of rotifer distribution among lakes in Ontario, Canada. Ecol Res 18: 639-650.

Cite this article as: Mwagona PC, Chengxue M, Hongxian Y. 2018. Seasonal dynamics of Zooplankton functional groups in relation to environmental variables in Xiquanyan Reservoir, Northeast China. Ann. Limnol. - Int. J. Lim. 54: 33 